Vol. 11 (1): 159-164 (2021)

\title{
DATA ON THE PAL YNOMORPHOLOGICAL FEATURES OF FOUR PLANTS OF ANEMONE GENUS, IN ELBASAN REGION
}

\author{
Blerina Pupuleku $^{1 *}$, Ermelinda Gjeta ${ }^{1}$, Gëzim Kapidani $^{2}$ \\ ${ }^{1 *}$ University of Elbasan "Aleksandër Xhuvani”, Faculty of Natural Sciences, \\ Biology Department, Elbasan, Albania; \\ ${ }^{2}$ University of Tirana, Faculty of Natural Sciences, Biology Department, Tirana, Albania; \\ "Corresponding Author Blerina Pupuleku, e-mail: blerina.pupuleku@ hotmail.com;
}

Received December 2020; Accepted January 2021; Published February 2021;

DOI: https://doi.org/10.31407/ijees11.122

\begin{abstract}
Palynomorphological features of four plants of Anemone genus, collected in fresh conditions in different areas of Elbasan region (Krastë-Elbasan, Ruen-Rrajcë, and Guri i Zi) were studied by light microscope X 400-1000. Similarities of aperture were identified, which appeared variable from three furrows at apenina, nemorosa, and ranunculoides plants to six or more furrows at hortensis plant. The sculpture of exine varied from microechinate to perforate at nemorosa, ranunculoides, and hortensis plants, varied from microechinate to reticulate at apennina plant. While furrows were sharp tips with membranes equipped with ornamentals. The pollen grains of Anemone apennina plant were the smallest ones in almost all dimensions among all palynomorphological features studied, except for the furrow length of pollen grains of Anemone ranunculoides plant, which appeared smaller than those of other plants studied. The biggest polar and equatorial axis dimensions were identified at Anemone ranunculoides plant, while in terms of exine thickness, the biggest size of pollen grains were found at Anemone hortensis plant.
\end{abstract}

Keywords: Pollen grains, exine, furrow, sculpture, Anemone, Elbasan. 